\title{
Collaborative Organization Models for Sustainable Development in the Agri-Food Sector
}

\author{
Salvatore Ammirato ${ }^{1, *(\mathbb{D}}$, Alberto Michele Felicetti ${ }^{1}$, Massimiliano Ferrara ${ }^{2}\left(\mathbb{D}\right.$, Cinzia Raso $^{2}$ and Antonio Violi ${ }^{3}(\mathbb{D}$ \\ 1 DIMEG—Department of Mechanical, Energy and Management Engineering, University of Calabria, \\ 87036 Rende, Italy; alberto.felicetti@unical.it \\ 2 Decision Lab, Department of Law, Economics, and Human Sciences, \\ Mediterranean University of Reggio Calabria, 89124 Reggio Calabria, Italy; \\ massimiliano.ferrara@unirc.it (M.F.); cinzia.raso@unirc.it (C.R.) \\ 3 Department of Law, Economics, Management and Quantitative Methods, University of Sannio, \\ 82100 Benevento, Italy; antonio.violi@unisannio.it \\ * Correspondence: salvatore.ammirato@unical.it
}

check for updates

Citation: Ammirato, S.; Felicetti, A.M.; Ferrara, M.; Raso, C.; Violi, A. Collaborative Organization Models for Sustainable Development in the Agri-Food Sector. Sustainability 2021, 13, 2301. https://doi.org/ $10.3390 /$ su13042301

Academic Editors: Giuseppe Marotta, Gaetano Martino and Concetta Nazzaro

Received: 18 January 2021

Accepted: 13 February 2021

Published: 20 February 2021

Publisher's Note: MDPI stays neutral with regard to jurisdictional claims in published maps and institutional affiliations.

Copyright: (c) 2021 by the authors. Licensee MDPI, Basel, Switzerland. This article is an open access article distributed under the terms and conditions of the Creative Commons Attribution (CC BY) license (https:// creativecommons.org/licenses/by/ $4.0 /)$.

\begin{abstract}
It is widely recognized that the adoption of collaborative organization models in the agrifood sector can help farmers in rural areas to reach sustainable development goals. In any case, a holistic and coherent view of sustainability, organizational models and supporting technologies in the agri-food sector is still not present in the scientific literature. With this paper, we aim to fill this gap and to propose a framework that is useful to help scholars and practitioners in analyzing and designing sustainable Collaborative Networks in the agri-food sector
\end{abstract}

Keywords: collaborative networks; sustainability; systematic literature review; framework

\section{Introduction}

The agri-food sector is experiencing profound transformations over recent years. Farmers have been facing several challenges such as rising of input costs, globalization, poor commodity prices and environmental pressure. As a result, many farmers have been forced to sell their farms and seek other jobs elsewhere, thus shifting economic activities and population to urban areas and exposing rural areas and rural communities to the risk of an economic, social and environmental decline [1]. For many years, development strategies were mainly based on economic growth pathways and the assumption that urban areas provide higher standard of living than rural ones [2,3]. Several authors recognized the important role of agri-food sector in promoting sustainable development [4,5], highlighting the multifunctional contribution of agriculture in indicating evolutionary paths of differentiation and integration of revenues for farmers operating in areas characterized by evident territorial structural weaknesses [6].

Changes are also evident on the demand side [7]. The behavior of consumers towards agri-food products is continuously evolving. Smaller and higher-educated family people started a slow revolution that is gradually changing conventional food consumption patterns [8]. Consumers have become more critical and outspoken and are more and more sensible to several food aspects linked to the quality, typicality, and provenance of production [9]. Values, such as well-being and quality of life, together with a renewed interest towards local food-culture and heritage, exerts a high degree on the way consumers perceive food value [10]. Modern consumers evaluate food products, paying attention to all the operations along the food value-chain.

In this context, companies operating along the agri-food value chain face the challenge of meeting consumers' needs and overcoming issues deriving from the overexploitation of natural resources, the modification of the landscapes and the shift of economic activities and population to urban areas [11]. In order to face these economical, societal and environmental challenges, agri-food companies address their choices towards investments in 
product, process and organizational investments in sustainable innovation and company responsibility. In fact, product and process innovation is widely recognized as a driver for improving the quality and safety of agri-food products [12], reducing environmental and societal impacts as well $[13,14]$.

In recent times, the convergence between new organizational models and ICTs paved the way towards new technologies and business models capable of improving the competitiveness of agri-food supply chains. If, on the one hand, this convergence offers new development opportunities for the agri-food sector, on the other hand, it raises specific coordination issues along the supply chain, requiring new coordination methods and new governance approaches among agri-food actors [15]. In this direction, farmers and other agri-food-related organizations spontaneously started to organize themselves in rural networks, with the aim to face problems of rural areas. New and alternative business models emerged in order to ensure a long-lasting competitive advantages, as well improving revenue streams and developing new market niches [16]. These new models are characterized by strict connection among consumers and producers in order to pursues explicit political and ethical goals: revitalize the identity of rural areas, promote relations among rural actors within the rural community, promote economic, environmental and socially viable practices within agri-food companies [17]. These networks are aiming to shorten social and physical distances between consumers and producers, reducing the number of intermediaries in the food supply chain, allowing local agri-food companies to become food system makers rather than food system takers in the new global economy [18-21]. The transition involves the whole supply chain rather than individual companies and requires a certain degree of collaboration among business, information collection and sharing and investments in technology innovation [22]. The adoption of appropriate collaborative-based technologies and management practices allows us to speed up the communication and information exchange between the various players operating in the supply chain, reducing the quantity of intermediaries as well as the downtime to which food is subjected in conventional logistics networks.

Supply chains in the agri-good sector are subjected to many sources of uncertainty that can negatively hamper performances of single actors and of the entire supply chain [23]. Several authors propose collaboration as an approach to mitigate this negative impact [24]. However, despite these potentials, the adoption of network-based paradigms is characterized by a certain degree of complexity. This complexity can be attributable to various factors, such as the incompatibility of the formats used to manage information, the large number of companies, the lack of trust between organizations, the heterogeneity in the culture and objectives of the actors involved [25]. A complete view of characteristics and issues that characterize collaborative networks in food supply chains is, therefore, necessary. This need is even more evident in sustainable supply chains where the objectives (both of individual operators and of the entire network) are heterogeneous and sometimes conflicting [26]. Several studies addressed the role of collaborative-based organizational models in addressing sustainability needs of agri-food supply chains. In particular, frameworks to model food supply chain governance and collaboration, according to a sustainability-oriented perspective, have been proposed. In [27], a conceptual framework for the assessment of food supply chain according to a process-oriented perspective (from farm to fork) has been developed. Govindan [28] proposed a framework based on drive indicators and barriers to achieve sustainable production and consumption in the food supply chain. Krishnan et al. [29] presented a framework for to redesign the food supply chain to improve environmental sustainability. However, there is a lack of works aimed at offering a systematic view of the benefits, criticalities and characteristics of these organizational approaches based on collaboration. In particular, many works based on the analysis of case studies of collaborative networks in food supply chains do not follow a defined and specific structure. This implies that some relevant aspects of these networks are not explicitly identified and that it is difficult to compare the collaborative aspects of two or more supply chains. Although the scientific literature underlines the need for coherence 
between sustainability, organizational models and supporting technologies in the agri-food sector, the literature lacks a holistic overview. Starting from these considerations, the analysis of foundational aspects and characteristics of collaborative-based organizational approaches as a tool for value-chain creation in the agri-food sector seems to be a promising field to be explored.

With this paper, we aim to fill this gap, highlighting structural elements and characteristics that help to make sense of the current body of collaborative networks literature in the agri-food sector. To reach this aim, we analyze, in depth, the literature landscape of collaborative networks supporting sustainable development in the agri-food sector, by means of a systematic literature review [30] to clarify the main topics around which the literature has grown. The systematic literature review highlights the research topics in the context of Sustainable Collaborative Networks in the agri-food sector, as fundamental entities that are valuable in characterizing organizational and business aspects of a sustainable agri-food chain.

\section{Collaborative Networks in the Agri-Food Sector}

Recent years have been characterized by a growing interest towards sustainable development of agri-food sector [31]. This sector is affected by a wide range of problems need that, according to several authors, must be addressed requiring specific tools for their correct identification and ad-hoc intervention policies constructed with a bottom-up and collaborative based approach [32-34].

Collaborative Networks is a broad concept: a proof of this is the array of different typologies in the scientific literature, such as knowledge clusters, virtual clusters, pure agglomerations, inter-organizational networks, or new industrial districts [35]. According to the flexible specialization school, the fundamental reason behind collaborative based approaches is "untraded interdependencies", characterized by informal and formal information exchange, interactions and shared rules to enable communication among partners and interpreting knowledge [36].

In the agricultural sector, new organizational networks based on processes of synergic collaboration between rural actors emerged in recent years to propose solutions for the rural community question. The enhanced competitiveness of agri-food SMEs and territories depends greatly on their ability to enter dynamic Collaborative Networks in open and increasingly virtual business environments [37]. Collaborative advantage for actors participating within the network usually consists of synergistic gain and program enhancement coming from resources, risks and rewards sharing, prioritizing collaboration against competitive advantage of each single stakeholder [38].

Collaboration is widely considered fundamental as a catalyst for farmers' empowerment and business development. Although farmers are key stakeholders in an agri-food supply chain, they typically experience limitations in their business-related skills, thinking style and aspirations [39]. Collaborative-based approaches can help farmers in overcome these limitations, facilitating them farmers to access opportunities benefits and resources equal to those of other supply chain stakeholders. In fact, the agri-food sector is characterized by a constellation of heterogeneous actors sharing values, culture and infrastructures that have the potential and the will to cooperate in order to pursue the general long-term objectives of territory development and competitiveness. This concept is known in the literature as Virtual Breeding Environment [40]. During the last decade, many successful experiences of collaborative agri-food networks highlighted the importance of setting-up organizational and technological aspects of a breeding environment to support socioeconomic development of a referred territory [41-43]. Many scholars see in the exploitation of the concept of food relocalization a mean of improving well-being, authenticity and, in a more general sense, the quality of life of rural areas [44]. Despite ongoing change, scholars affirm that rural areas remain characterized by the relative abundance of natural capital, identifying in the agri-food sector the opportunity to revitalize the economy of rural areas and territorial identity $[45,46]$. Organizational and technological models, 
based on the Collaborative Networks paradigm, have been proposed to manage bottom-up aggregations of local economic operators, causing impact on the territorial attractiveness with remarkable results in terms of sustainability, preservation of historical and natural heritage and resource optimization [47]. Various studies state that rural actors might be able to realize their expectations through the exploitation of collaborative organizational forms, by shortening long and complex agri-food supply chains [48]. Such alternative ways are seen as a way to foster the sustainable development of rural communities, reducing producers' dependence on subsidies and increasing territorial competitiveness. These kinds of collective initiatives attempt to put into practice sustainability-related issues, creatively reshaping conventional agri-food chains [49,50]: multi-functional farm enterprises, new premium quality food production place-based production, revitalization of territory identity and socio-cultural heritage.

Collaboration-based approaches take on even more significance in light of the opportunities for the development of so-called circular economy, through innovative technologies and profitable business models based on the exploitation of agricultural wastes, byproducts and unsold products [51]. The development of a Circular Economy-based model requires the adoption of new coordination methods among different phases of the food value chain. The development of such a model moves away from traditional linear production systems operating through the conversion of natural resources into products and then wastes. Circular Economy in food chains includes all the activities aiming to reduce, reused and recycled material along the food supply chain [52]. Cooperation among stakeholders in food supply chains is considered mandatory in order to achieve sustainability-oriented goals [53], since the companies along the supply chains pursue different objectives and that sustainability goals (individual and collective) are often conflicting with each other [54]. Many works emphasize the role of circular approaches in conciliating economic and environmental and social objectives in sustainable food supply chains [55]. Particular attention is paid to the approaches aimed at reducing food loss and waste, seen as a critical aspect for achieving social and environmental objectives but also in terms of economic sustainability for supply chain companies [56]. Coordinated and coherent actions fostering a shared vision for sustainable development should be designed [57], bearing in mind that initiatives to reduce food waste in a given stage of the supply chain could have a negative impact on companies operating in subsequent stages [58]. The culture of collaboration [59] and the implementation of appropriate standards (e.g., HACCP) [60] can positively contribute to the reduction in complexity along supply chain and to the achievement of sustainabilityoriented goals. Consumers' roles in the sustainable food supply chain is gaining more and more importance. Nowadays, also in the linear economy, consumers are no longer relegated to the simple role of passive buyer [61]. However, this effect is even more evident in closed-loop supply chains, where consumers are increasingly involved in innovation processes and in interactions with other stakeholders in the supply chain, with considerable implications for coordination in reverse logistics [62]. An issue that is particularly taken into consideration both by academics and practitioners concerns the role of the consumer in food waste management [63-67]. These aspects have been made even more relevant by the recent COVID-19 outbreak, due to growing food insecurity [68] and the importance of community engagement [69].

\section{Methodology}

We carried out a systematic literature review to provide a complete, exhaustive summary of relevant literature addressing the characteristics of sustainable collaborative networks in the agri-food sector. According to the methodological framework proposed by Denyer and Tranfield [30], our research methodology was organized in three phases: papers location and selection, papers analysis and classification, definition of themes. 


\subsection{Papers Location and Selection}

To gather the relevant scientific literature on Sustainable Collaborative Networks in the Agri-food sector, we selected Scopus and Web of Science (WoS) databases. These two databases are widely considered to be the most comprehensive and relevant databases for academic articles and, in particular, in managerial studies [70-72].

The search was performed using wildcards and Boolean operators, following the features of each database. The search was performed at the beginning of October 2020. The steps of the methodology we followed are below described, while Figure 1 shows the workflow we adopted:

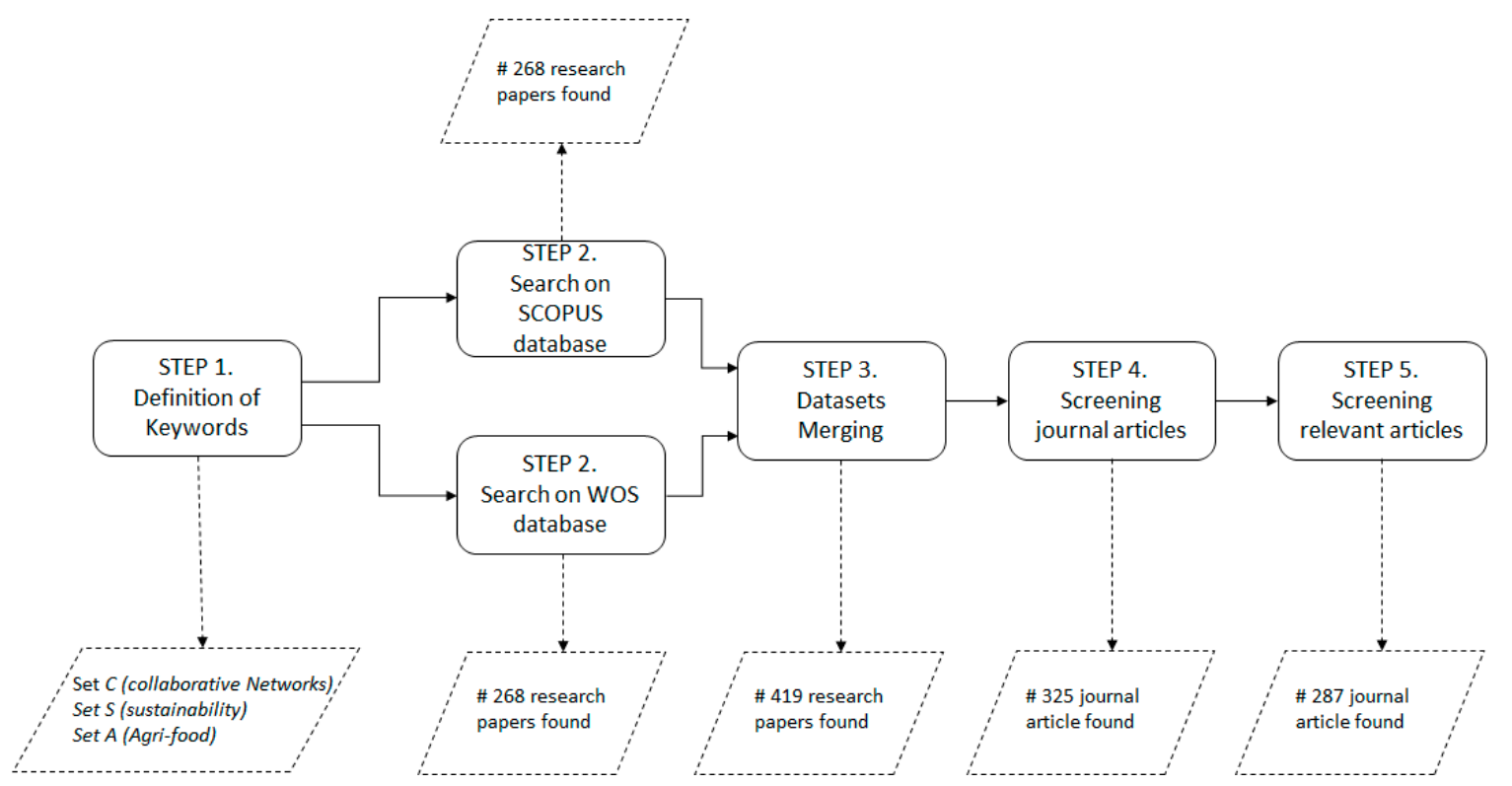

Figure 1. Papers location and selection Workflow.

Step 1-Definition of keywords: we defined three set of keywords, namely:

- $\quad$ Set $C$, including terms related to the Collaborative Networks field of study. The set was build considering the taxonomy of collaborative-networked organization provided in [73].

- $\quad$ Set $S$, including terms related to the Sustainability field of study. The set was defined considering suggestions provided in [74-76].

- Set $A$, including terms related to the agri-food field of study. The set was defined considering the classification of agri-food -supply chains provided in [77].

Step 2-Search process: the keywords were constructed into search strings, to administer the search to Scopus and WOS scientific databases. The following search string was structured: The search must contain at least one keyword of the Collaborative Networks domain (C), one keyword from the Sustainability Domain (S) and one keyword from the Agri-food Domain (S). We were able to find 388 and 268 papers, respectively.

Step 3-Datasets merging: we merged the two datasets and we manually analyzed metadata (authors, title, source, and year) to detect duplications. Through this procedure, we identified a list of 419 scientific works.

Step 4-Screening journal articles: following suggestions provided in (e.g., [71,78-80], we selected only articles published in peer reviewed journals omitting books, book chapters, discussion papers, and non-refereed publications. This is an approach adopted in many organizational studies to ensure rigor of contents. A total number of 325 entries is indexed as journal papers.

Step 5-Screening relevant articles: finally, we limited our research to the organizational and managerial field of studies. We have taken into account papers published 
in journal indexed at least in one of the following subject area: "Engineering"; "Social Sciences"; "Business, Management and Accounting"; "Decision Sciences"; "Economics, Econometrics and Finance", excluding papers published in journal indexed in medicine, chemistry, pharmacology, and biology fields of study. At the end of this process, we obtained a final set $\mathrm{P}$ of 287 papers.

In Figure 2, a graphical representation of sampled papers in $\mathrm{P}$ clustered by publication year is shown.

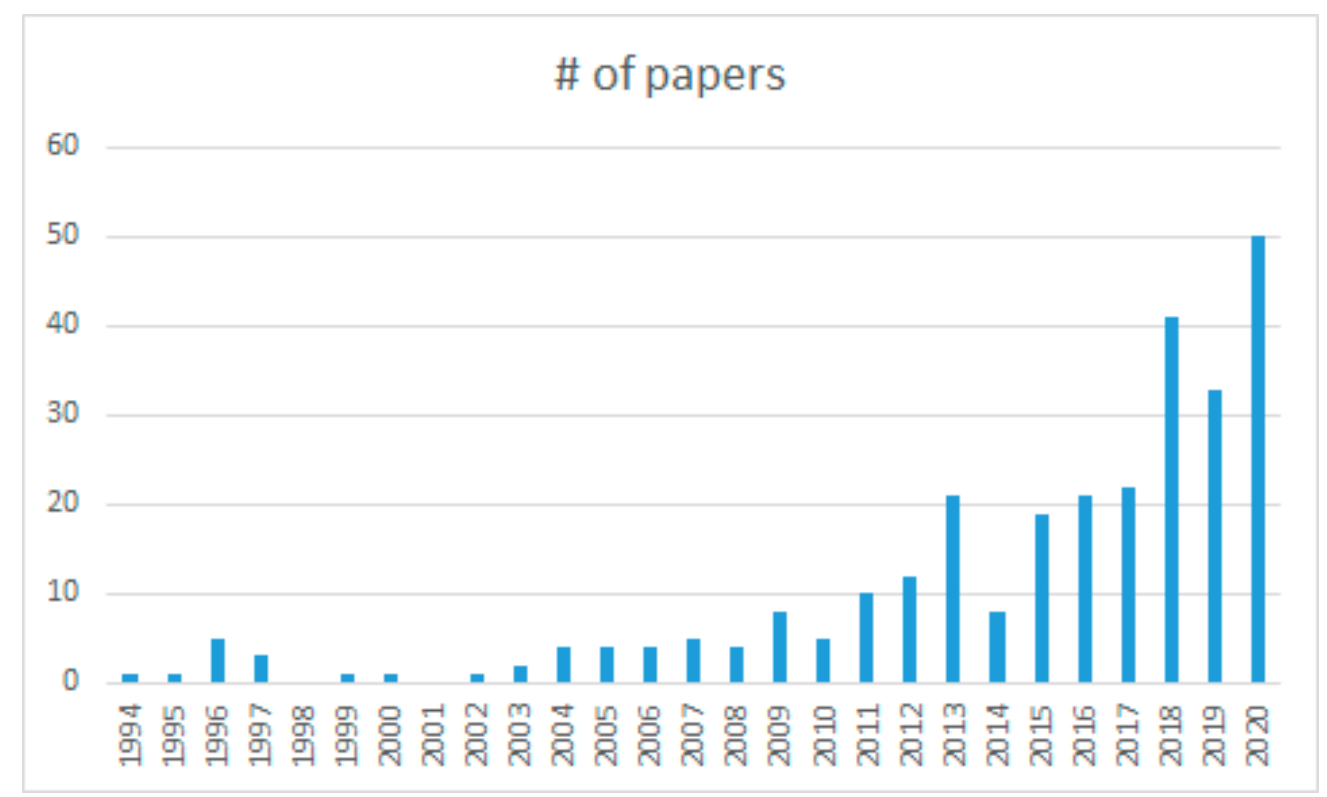

Figure 2. Papers in $\mathrm{P}$ by publication year.

\subsection{Papers Analysis and Classification}

We carried out a quantitative analysis based on the Latent Dirichlet Allocation (LDA) in order to identify main topics in the context of Sustainable Collaborative Networks in the agri-food sector.

This approach led to the identification of a Document-Term Matrix-that is a matrix describing the relative presence of keywords within the papers we analyzed. For each document, the LDA procedure measures the portion of document belonging to each topic, namely, topic proportion. This method takes as input the documents to be analyzed (in our case, the set $P$ of papers) and several topics, $k$, to be extracted. Following suggestions provided in $[81,82]$, we have chosen $k$ in such a way that the interpretation of the machinegenerated model results becomes as easy as possible from the point of view of a human reader. We evaluated several results of the LDA procedure with $k$ ranging from 2 to 20 and we have consensually agreed that the most meaningful set of topics is reached with $k=10$.

The LDA procedure gave as output a group of significant keywords associated with each topic, as presented in Table 1.

\subsection{Definition of Topics}

We carried out a human-based review of representative and relevant papers, to provide a meaningful description of each topic. Following suggestions provided in [83], we reviewed papers matching the following criteria:

- Papers published in academic journals ranked at a " $\mathrm{C}$ " level or higher of the German Academic Association for Business Ranking or equivalent values of ISI Impact Factor (IF $\geq 0.7$ ).

- Papers with a topic proportion value of 0.25 or higher. 
Table 1. Keywords grouped by topics as output of Latent Dirichlet Allocation procedure

\begin{tabular}{cccccc}
\hline Topic 1 & rule & behav $^{*}$ & govern & Standard & operat $^{*}$ \\
\hline Topic 2 & trust & relation & transparen & reliab & behav $^{*}$ \\
\hline Topic 3 & indicat $^{*}$ & performance & assess & measure & Efficiency \\
\hline Topic 4 & collaborat $^{*}$ & goals & integrat $^{*}$ & Effort & Commitment \\
\hline Topic 5 & organiz $^{*}$ & network & Model & compan $^{*}$ & Structure \\
\hline Topic 6 & technolog $^{*}$ & information & Data & Traceability & Ict \\
\hline Topic 7 & compan $^{*}$ & stakeholder & Role & Participant & collaborat \\
\hline Topic 8 & model & optimiz & Objective & mathematical & operation \\
\hline Topic 9 & system & operation & Process & Model & method \\
\hline Topic 10 & process & activity & Circular & Lifecycle & Operation \\
\hline Note: ${ }^{*}$ at the end of a word means that it can be completed in whatever way to be used as a keyword.
\end{tabular}

\section{Results}

In what follows, we present a description of topics that emerged as an output of the LDA procedure. We assume that these research topics address fundamental entities that are valuable in characterizing organizational and business aspects of a sustainable agri-food chain. The discussion is built on the interpretation of keywords and on the analysis of relevant papers and main studies they cited.

Topic 1: Network governance. This topic deals with governance rules, policies and principles driving the behavior of members in an agri-food supply chain. Collaboration is widely recognized as a key element to reduce conflicts in supply chains, fostering the responsibility of each participant to guarantee the achievement of sustainability-related objectives [84]. The definition of appropriate rules governing the behavior of the members within a collaborative network is fundamental to reducing their opportunistic and individualistic behavior, in favor of shared long-term objectives [85]. A broad body of literature recognizes the importance of standards in agri-food supply chain governance. Standards mainly emerged to face consumer concerns about food safety and quality [86]. As well as having a huge impact on the quality and safety of food product, private and public standards affect the internal organization of firms, the organization of the whole supply chain, the distribution of profits and the welfare of all stakeholders [87].

Topic 2: Prescriptive behavior. Another relevant aspect influencing company behavior deals with transparency and trust along the food supply chain [88]. According to Bastian and Zendes [89], supply chain transparency is a key prerequisite for sustainable agri-food supply chains. Legal and obligatory requirements have represented, for a long time, the main approach to guarantee transparency and food quality and safety. In any case, the last few decades of striving towards cooperative operational optimization, as well as ecologically and socially sound supply chains, have yielded new exigencies [90,91]. Food supply chains are becoming even more large and complex. This opens many sustainable related issues for agri-food chains. It is mandatory to increase the transparency and traceability of food supply chains since consumers are more and more interested in social and environmental concerns $[43,92,93]$. Trust is regarded as an important asset in an exchange relationship between food supply chain members. Susanty et al. [94] found that collaborative communication, power dependency and price satisfaction have a positive and significant effect on trust between individual farmers in the dairy supply chain.

Topic 3: Performance Assessment. Scholars recognize the importance of defining and assessing sustainability performance indicators to produce and deliver sustainable agri-food products along the supply chain [95]. A performance measurement system in a sustainable agri-food supply chain can be defined as the design, the use, and the assessment of a set of metrics aiming at quantifying efficiency, effectiveness and relationships along multiple firms according to a social, environmental and an economic perspective [96]. However, 
although several approaches to measure sustainable-related performances are proposed in the literature $[97,98]$, the sustainability performance assessment is considered hard to implement, mainly due to alignment, and the effort and clarity needed by all the companies in the supply chain $[99,100]$. This calls for a great commitment of all involved organizations towards the elicitation of the benefits arising from the use of an appropriate measuring system and the definition of guidelines to implement and use the obtained information [101]. As previously stated, several works on sustainable agri-food supply chains have identified a broad range of indicators assessing companies' economic, environmental and social practices in their supply chains. Although from an operational point of view, indicators adopted may vary mainly due the different nature of each supply chain (e.g., supply chain size, type of food, regulatory concerns), scholars agree in grouping these indicators according to the three classic pillars of sustainability [102-105]. For example, some environmental indicators may concern water use, soil erosion and pollution prevention, fertilizer and pesticides reduction, biodiversity preservation, carbon footprint, GHG emissions [106]. Socio-ethical indicators may regard animal welfare, gender equality, food safety, working conditions, and child labor [107]. Economic aspects may concern profit sharing among supply chain actors, lead times, access to markets, knowledge, and technology transfer [108].

Topic 4: Intensity of Collaboration. Some studies addressed the impact of the intensity of collaboration (i.e., the mutual engagement of participants) on agri-food supply chain operations [109]. As the level of integration among supply chain members increases, it increases the amount of common goal-oriented risk taking, commitment, and resources that participants must invest into the joint endeavor [73]. This implies mutual trust and thus takes time, effort and dedication of participants towards the achievement of shared goals. In the literature, different forms of classification related to the intensity of a collaboration in a supply chain are identified. In [73], the authors identify four coalition's types, namely networking, coordination, cooperation, collaboration. Grosvold et al. [110] explore the conditions under which firms align their activities according to the following levels of intensity: decoupled, loosely coupled and tightly coupled alignment. In $[111,112]$, the authors identified the following phases cooperation, coordination, and collaboration. It is worth highlighting that these works see coordination as a higher level of integration than cooperation, unlike what was noted in [73]. In [113], the authors developed a classification framework that takes into account the social capital dimension and organizational performances in agri-food supply chains according to each level of collaboration. Rota et al. [114] studied levels of collaboration among partners in Egyptian food organic and fair-trade chains. They defined a collaboration index based on three constructs: information sharing, decision synchronization and incentive alignment. In [91], the authors appraised the potential role of buyer-supplier collaboration and relations and their relevant opportunities in the power-laden, contentious environment of the retail grocery sector. They proposed a framework to classify collaboration in food supply chains according two dimensions: intensity of collaboration (low, high) and complexity of collaboration (low, high). This allowed for identifying four collaboration typologies, ranging from a purely transactional approach to a long-term partnership.

Topic 5: Organizational forms. The high dynamicity of the food industry and the need to face sustainability challenges calls for a wider ability to adapt and reconfigure organizational settings along the whole supply chain [115]. Several works emphasize the need for coordination and collaboration in the food industry [116], mainly due to the need to ensure the safety and quality of food products [117]. Some studies focused on organizational models of sustainable food supply chain characterized by the presence of a focal company in large-scale distribution, around which the inter-organizational structure of the entire supply chain is defined [118]. Kirci and Seifert [119] proposed a holistic framework characterized by a three-tier organizational structure. They presented an application of the framework on the "zero waste to disposal" initiative of Nestlé. Pohlmann et al. [120] discussed the role of the focal company in designing a sustainable supply chain in the Brazilian poultry industry. Sellitto and Hermann [121] presented an organizational model 
of green supply chain in the peach industry. These experiences are all characterized by the fact that the focal company has a strategic role in implementing new trends in sustainability, such as corporate social responsibility and green supply chain management [122]. Several papers systematized collaborative approaches based on territorial embeddedness and reconnection with consumers. Such initiatives have been labelled either as Alternative Food Networks or Short Food Supply Chain [123]. Renting et al. [124] provided a classification of organizational structures for alternative food networks. They identified three main categories of organizational forms, namely face-to-face, proximity and extended short food supply chains. Sacchi et al. [125] conceptualized five types of short food chain along the continuum that goes from the network type of governance towards the more bureaucratic types. Volpentesta et al. [126] proposed a classification of main basic form of Direct agri-food chains (e.g., direct farms, farmers' markets, box-scheme, collective supported agriculture, community kitchens). The authors agree that short food supply chains are widely believed to be more sustainable in comparison to mass food delivery systems [108].

Topic 6: Digitalisation of Supply chains. Innovation in ICTs and digitalization led to a new phase in sustainable agri-food supply chains. A wide range of literature on the role of ICTs applications addressing several issues of agri-food chains, e.g., climate monitoring [127], data monitoring during pre- and postharvest operations [128], precision agriculture [129], traceability [130] and distribution [131]. ICT-based solutions allow for the monitoring of food supply chain more efficient, reducing delivery time, costs and waste due to food products expiring in warehouses $[132,133]$. ICT adoption is suitable to make the supply chain capable of quick response and performance improvement [134]. Several authors addressed the role of ICTs in enabling the food supply chain with risk management tools, allowing companies to distribute food products with full confidence [135]. Supply chain actors can communicate at a faster rate, reducing variability and uncertainty in the system $[136,137]$. In sustainable agri-food supply chains, ICTs play a crucial role to guarantee coordination, transparency, and traceability [138]. On the one hand, this helps to ensure food safety and effective information to consumers [139], while on the other hand helps stakeholders to know the input materials along with forward and backward tracking [140]. The role of ICTs is accentuated by the fact that agri-food products are "embedded" with value-laden information, concerning the mode of production, provenance, and distinctive quality assets [141]. Such information/knowledge exchange may be supported by new types of services, based on recent technological developments. Mobile services can provide information offerings regardless of temporal and spatial constraints, bringing supply chain actors closer to each other [142]. Mobile services for agri-food supply chains may regard Location-Based Services and Geospatial Services, Social Networking, Virtual Visits and Traceability [143]. Technological advances in food sensor miniaturization have made possible the development of lab-on-smartphone platforms for mobile food diagnostics that allow for a rapid and on-site food analysis for preliminary and meaningful food information extraction [144]. The availability of new smart food applications and devices (e.g., "food scanner" or "food sniffer" for food analysis) suggest that the time is right to conceive new approaches to food information management that would empower supply chain's actors and be more responsive to their information needs [145].

Topic 7: Actors and roles. Some works are devoted to the identification of actors and the definition of roles within sustainable food chains. Sustainability issues in food supply chains call for integrative approaches including several types of partners, stakeholders and consumers [146]. Sustainable food chains are characterized by a high degree of empowerment of members [147]. This approach is indispensable for us to guarantee the main features to address relocalisation, identity and social welfare, which are at the core of socio-economic development of agri-food communities [148]. Most successful experiences of sustainable food supply chains highlight the importance of identifying the right participants in a collaborative setting [149]. Although these actors can be heterogeneous in terms of their operating environment, they must share values and culture, organically orienting 
themselves towards the achievement of common long-term objectives [150]. In [21], the authors defined the main actors and roles needed to build up an alternative agri-food network. Moreover, they emphasized the role of a trusted third party in overcoming some typical issues (e.g., lack of common goals, languages, values and mental schemes) that can lead to the failure of the initiative. O'Reilly et al. [151] analyzed the case of the Parma Ham consortium, deepening relationships among network members. They found that the competitiveness of the Parma Ham network is, to a large extent, based on external collectively owned competencies. Although the network relies on governance mechanisms, research evidences strong ties among producers. The impact of individual group members' heterogeneous characteristics, resources and strategies on the Parma Ham consortium has been investigated in [152]. Van Der Vorst et al. [153] analyzed food supply chain networks in terms of the parties involved, product characteristics and alternative redesign strategies. They identified main actors for two main types of networks: fresh agricultural products chains (e.g., growers, auctions, wholesalers, importers and exporters, retailers and specialty shops and their logistics service suppliers) and processed product chains (e.g., growers, importers, food industry processors, retailers and out-of-home segments and their logistics service suppliers).

Topic 8: Mathematical programming models. A huge body of literature relies on operations research techniques to achieve economic, social, and environmental sustainability in the food supply chain domain. Soto-Silva et al. [154] reviewed the literature on operational research models applied to the fresh food supply chain. They classified research according to the following dimensions: decision levels (strategic, tactical or operational horizon), analytical modeling approach (e.g., linear programming, nonlinear programming, stochastic optimization, dynamic programming) and purpose (sowing, production, harvesting, distribution or inventory). In [131], the authors perform a literature review classifying mathematical models in single objective and multi-objective problems, and according to the three pillars of sustainability. Most parts of the papers dealing with a single-objective approach consider social and environmental issues as constraints of the problem, while cost/revenue are considered as an objective $[155,156]$. Other works focused on social and environmental objectives. For example, in $[157,158]$, the main objective was to optimize deals with animal welfare, while in [159], a model to minimize the number of undistributed products to food banks is presented. Some examples of environmental objectives are provided in [160], where the authors minimize land use and in [161], where a model to reduce carbon footprint is presented. In many cases, operational research approaches in sustainable food supply chain management are based on multi-objective models. Govindan et al. [162] proposed a routing problem with time windows that aim to minimize environmental impacts and logistic costs. A similar approach is proposed in [163], where the authors proposed a model for the sustainable distribution of perishable food, considering operating costs and carbon footprint. Azadnia et al. [164] developed a multi-objective approach for lot sizing and sustainable supplier selection, with the aim to minimize total costs and maximize social and environmental scores. In [165], the authors proposed a stochastic programming approach for the integrated inventory-routing problem in which products with high perishability must be delivered form a supplier to a set of customers with an uncertain demand.

Topic 9: Operations Management methods and tools. Many works are devoted to the definition of methods and tools supporting the design and the control of business operations in the sustainable production and distribution of food products. Life-cycle assessment (LCA) is a predominant approach to study environmental aspects and potential impacts throughout product's life cycle along the food supply chain, through production, product use and disposal. LCA represents a useful tool to assess resource use, energy and environ-mental burdens related to the full life cycle of products and services and it is widely used for analysis of the sustainability of the agri-food sector, ranging from single products applications to more in-depth analyses of the sustainability of a supply chain [166]. The main challenges of LCA to support sustainable agri-food systems are exhaustively addressed by a review 
carried out by Notarnicola et al. [167]. Papers based on LCA are mostly focused on specific case applications: e.g., olive-oil supply chain [168], tomato sauce [169] and apple [170]. Some works propose simulation-based approaches to understand the behavior of food supply chains. According to Ivanov [171], simulation modelling methods allow us to visualize network operations, to trace processes and observe the impact of different action in a sustainable food supply chain. System dynamics modeling for sustainable supply chain management is a widely used simulation approach [118]. System Dynamics provide a framework to analyze how actions and reactions cause and influence each other, and how and why elements and processes in the system change. For example, in [172] a system dynamics approach was used to study the behavior and to determine the impact of demand variability and lead within a supply chain for non-perishable food products. Taghikhah et al. [173] proposed system dynamics modeling for a case of wine-extended supply chain. Zhu and Krikke [174] adopted system dynamics simulation to assess scenarios for a cheese supply chain after the COVID-19 outbreak. Advancements in ICT have made a rethinking of business processes necessary so that the introduction of new solutions have the highest possible impact on company and supply chain performances [175]. Business Process Modelling is important to understand and restructure activities and information flows within food supply chains. Some works use Business Process Modelling Notation (BPMN) to conceptualize processes within sustainable food supply chains [176-178]. Other works are based on the SCOR (Supply-Chain Operations Reference) model $[99,179,180]$.

Topic 10: Supply chain process management. Some papers addressed activities that characterize collaborative networks in the agri-food sector. Authors agree in classifying the activities of networks in the agri-food sector along three fundamental phases, namely creation, operation and dissolution of the network [181,182]. Partners selections and formal constitution on the collaboration represent the main activities during network creation phase $[183,184]$. Research works dealing with the operation phase mainly address collaborative activities needed performed at a network level. Such activities are usually performed by focal companies or trusted third parties within food supply chains [185]. In [186], an exhaustive literature review addressing typical collaboration-based activities in food supply chains is presented. A new literature stream specifically devoted to sustainable food supply chains consider collaborative activities based on the circular economy paradigm. Particular attention is paid towards reverse logistics, post-consumer packaging and waste management activities in food chains, is paid in [187-190]. Although the dissolution phase has been identified as relevant in the life cycle of agri-food networks, no works specifically dedicated to this phase have been identified. However, in [190], some elements related to the dissolution phase, such as the redistribution of assets, are presented.

\section{Discussion: Towards a Framework to Characterize Sustainable Collaborative Networks in the Agri-Food Sector}

The analyzed topic attracts always more scholars from different disciplines thus highlighting its increasing importance from both the academic and the economic points of view (see Figure 2).

With the aim to offering a systematic view of the benefits, criticalities and characteristics of the sustainable collaborative networks in the agri-food sector, we further analyzed results of the systematic literature review in order to identify topics presenting similarities and common elements. The critical reading of the results led to the identification of four themes clustering the ten topics. From an operational perspective, each theme represents a main aspect characterizing organizational and business features of sustainable collaborative networks in the agri-food sector.

In this section, we propose a conceptual framework for Sustainable Collaborative Networks in the agri-food sector that can be useful to reach a twofold goal. From the one side, the framework summarizes the four themes, the ten topics and their connections as resulted from the literature review. From the other side, the framework can be useful to characterizing the foundational aspects, principles, and practices of Sustainable Collabora- 
tive Networks and thus can be useful to help practitioners in the analysis and design of Sustainable Supply Chains in the Agri-food sector.

\subsection{Theme 1: Network Structure}

This theme deals with the definition of constitutive elements of a sustainable collaborative network in the Agri-food sector, both in terms of organization of the whole network and characteristics of individual components. As emerged from the analysis of the literature, there are various organizational configurations that can be assumed by a collaborative network in the agri-food sector. This aspect is strongly connected to the strategic objectives of the network and the temporal orientation of the collaboration.

Structural traits can be defined in terms of topological characteristics of the collaborative network, i.e., hierarchical relationships, intensity of connections and characteristics of each node. These traits can be, respectively, represented by organizational forms, intensity of collaboration and actors and roles described in Section 4.

Sustainability oriented objectives require a high ability to adapt and reconfigure organizational settings to ensure safety, quality, and transparency for consumers. These organizational models require a direct connection with consumers and a close territorial embeddedness. Main dimension characterizing organizational forms in sustainable agrifood collaborative networks concerns:

- The temporal and spatial proximity between producers and consumers [124].

- The role of a focal company in the activation of the collaboration initiative (top-down vs. bottom-up approach) [123].

The intensity of collaboration, i.e., the level of engagement of each participant in agri-food supply chain activities represent an aspect that is strictly intertwined with the adopted organizational form. Some organizational forms are more appropriate than others depending on the level of involvement of networked actors. From the analysis of literature, we can argue that the more the level of integration among supply chain members increases (from networking to collaboration), the more risk and social capital, resources and activities are shared among partners.

Characteristics of involved partners and role performed within the network represent the last aspect that determine the structure of the network. Collaboration efforts within agri-food systems call for an integrative approach that invites and includes different types of partners, integrating stakeholders and consumers in a network where partners are treated as active network members, playing a participatory role instead of being names on partnership's membership lists that only give the appearance of social inclusiveness. The number and the type of participants depends on the strategic objectives of the networks, the competence needed to carry out network activities and the specific characteristics of the supply chain (e.g., fresh vs. processed food). Besides typical players that characterize food supply chain (e.g., growers, food processors, logistics service suppliers, retailers, and specialty shops), sustainable collaborative networks are characterized by the presence of trusted third parties able to manage typical issues in bottom-up networks. These entities usually play an intermediate role among networks members, as collaboration catalyst, technology intermediary and guarantee authority.

\subsection{Theme 2: Participants Behavior}

Participants behavior is a relevant theme of sustainable collaborative networks in the agri-food sector. Literature review shows that behavioral aspects can be summarized in network governance and prescriptive behavior and performance assessment.

The first element deals with mandatory rules and policies that must be followed inside the network. These rules govern the functioning of the collaboration throughout its life cycle, from its creation, to its functioning and its dissolution. This includes not only the national and international regulations in force but also the specific conditions of adhesion and participation in the network. With a specific reference to the agri-food sector, rules and 
public and private standards aimed at guaranteeing transparency and quality throughout the supply chain are recognized to be of great importance.

Trust and transparency represent a key prerequisite for sustainable agri-food supply chains. Ecological and social expectations, shared values and business culture represent a set of principles generally accepted and promoted among network members. Since sustainable collaborative networks in the agri-food sector are characterized by a close connection with the territory, regional culture, and traditions play an important role in the behavior of the actors and in their relationships. Sharing culture is a central aspect in prescriptive behavior. Resources, responsibility, and risk sharing require high commitment and mutual trust. Appropriate policies to distribute liabilities and rewards are required. High level of trust and commitment have a significant contribution to supply chain performances. Actors are led to pursue long-term interests on a Collaborative Networks as the fear of opportunistic behavior by supply chain alliance participants decreases. From the literature review emerged that this is particularly true in sustainable food supply chain where a high commitment towards financial and non-financial objective is required. Scholars agree that this requires an appropriate elicitation of the benefits arising from the use of an appropriate performance measuring system. Performance indicators are grouped in three main categories, namely environmental, socio-ethical and economic indicators.

\subsection{Theme 3: Supply Chain Process Management}

Along sustainable agri-food supply chain systems, a collaborative oriented approach is needed to pursue common goals, increase profits, minimize costs, reduce environmental impact and assure quality for consumers and other stakeholders. Depending on the stage of the collaborative network life cycle (i.e., creation, operation, and dissolution) different activities need to be carried out.

During the creation phase, the main activities are the identification and selection of potential partners, the definition of the governance structure and the formal creation of the network.

In the operation phase, collaboration involves activities, such as production, transformation and distribution process and infrastructure management. In addition to these traditional activities, sustainable food supply chains are characterized by the presence of activities typical of circular economy approach, based on the exploitation of agricultural wastes, byproducts, and unsold products. Depending on the level of integration of the collaborative network, there are different activities that can be managed at a network level rather than by individual operators. Typically, these activities can be carried out by the focal company or by a trusted third party that manages the network and may concern marketing, logistics, consulting, community engagement and information and knowledge sharing.

The process of collaborative network dissolution is complex and, therefore, must be properly planned and defined from a contractual point of view. Although the actors involved are no longer partners, dissolution activities continue until debts are settled and tangible and intangible assets have been redistributed among partners.

\subsection{Theme 4: Supporting Tools, Methods and Technologies}

The appropriate deployment of supply chain activities is guaranteed by a series of tools, methods and methodologies that support network operations and management throughout its life cycle.

Over the years, several tools and methods have been developed to achieve economic, social and environmental sustainability in the food supply chain domain. A huge body of mathematical models and simulation-based approaches favor the optimization of production and distribution activities in food supply chains.

ICTs paved the way to a new phase in sustainable agri-food supply chains. A wide range of ICTs solutions support back-end and front-end processes of agri-food chains, with a relevant impact on economic, social, and environmental performance of the whole network. Companies can communicate at a faster rate, reducing uncertainty, guaranteeing 
at the same time coordination, transparency, and traceability. This evolution has been made even more evident thanks to mobile- and internet-of-things-based technologies.

Advancements in ICTs were accompanied by a rethinking of business processes to maximize the impact on supply chain performances. A wide range of Business Process Modelling tools, e.g., BPMN and SCOR, are available to conceptualize processes within sustainable food supply chains. With specific reference to sustainable food supply chains, life-cycle assessment (LCA) is a predominant approach to studying environmental aspects and potential impacts throughout a product's life cycle along food supply chain and to assess resource use, energy and environmental burdens related to the full life cycle of products.

A synthesis of the framework is represented in Figure 3.

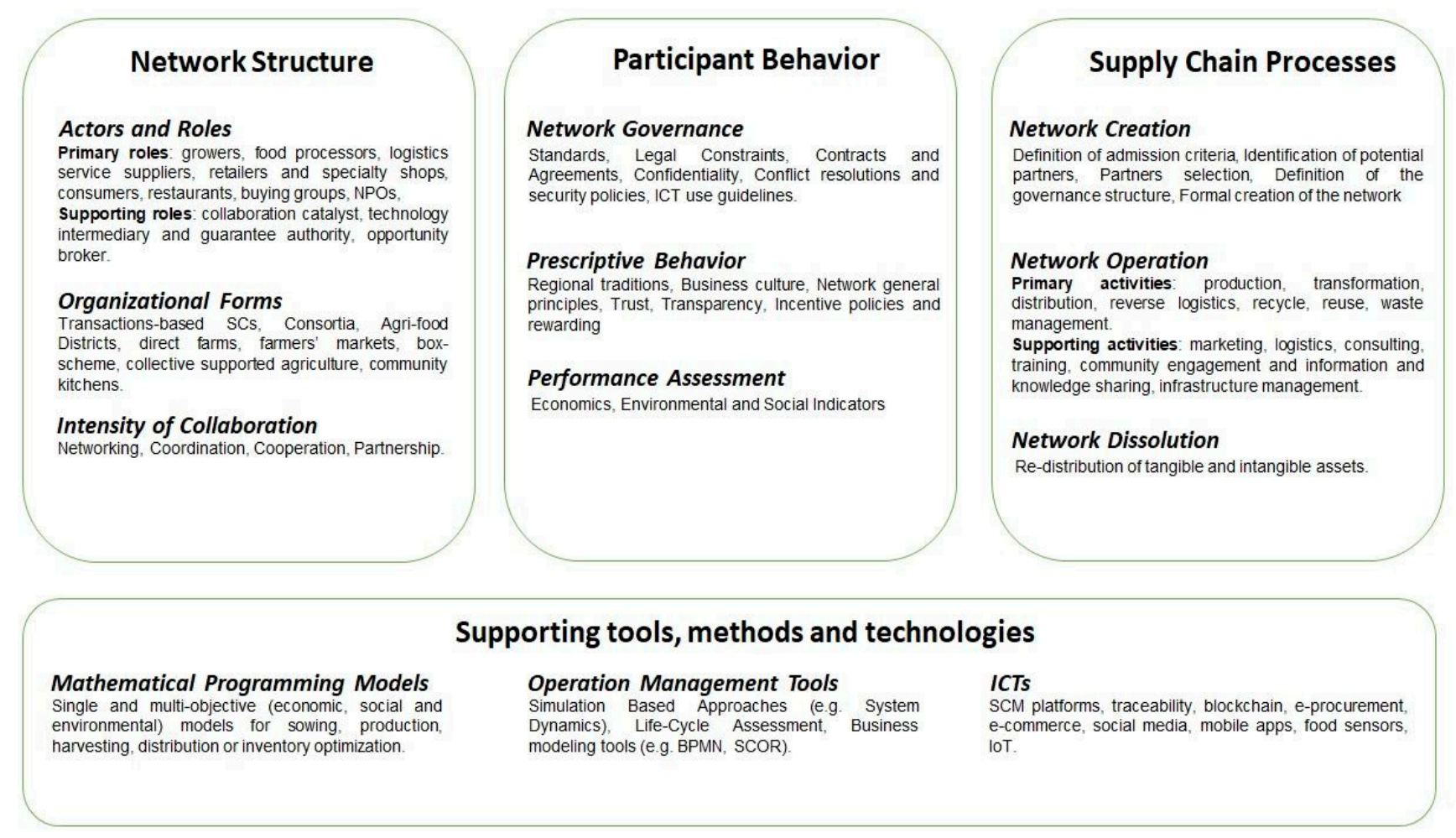

Figure 3. The framework to characterizing the organizational and business features of sustainable collaborative networks in the Agri-food sector.

\section{Conclusions}

Collaboration is widely recognized as a key element to reduce conflicts in food supply chains, fostering the responsibility of each participant to guarantee the achievement of social, economic, and environmental objectives.

Considering the high dynamism and uncertainty of the reference context, food supply chain operators are forced to develop new skills, new methods, and new structured approaches to face the challenges of the global market. The use of a reference modeling framework capable of capturing the complexity of collaborative-based approaches in sustainable food supply chains can represent a valid support for planning and managing these organizational networks appropriately.

We found in the literature a significant number of studies dealing with basic aspects of Sustainable food supply chain management. The attention of the literature has so far concentrated mainly on the evaluation benefits of sustainability-oriented strategies and advantages for involved parties, with a particular focus on how sustainability strategies have a positive impact on food quality, transparency and consumer trust. However, less attention has been paid towards the implications and issues of collaboration between 
different business organizations in sustainable food supply chains. The results of our systematic literature review led to the identification of ten topics clustered in four main themes dealing with collaboration in sustainable food supply chains, namely the Network structure, Participants behavior, Supply Chain Processess, Supporting tools, methods and technologies Network structure food sectors. The framework we proposed (summarized in Figure 3), give a holistic and coherent overview between sustainability, organizational models and supporting technologies in the agri-food sector.

The framework can be useful to help scholars and practitioners in analyzing and designing sustainable Collaborative Networks in the agri-food sector. Sustainable supply chain management in food sector presents several critical points along the whole product lifecycle, from farm to fork. Important collaborative-related issue in food chain sustainability may regard production (e.g., developing a shared culture of sustainability among producers, definition of social and environmental oriented standards, rational food loss management) procurement (definition of sustainable oriented criteria in supplier selection procedures, maintaining relations among partners), distribution (minimize empty runs, reduce emissions, choose environmentally friendly means of transport, define reverse logistic procedures) and consumption (rational waste management, alternative use of leftovers and expired food).

Collaborative Networks in the agri-food sector, as depicted in the proposed framework, can be an effective tool to reach the goals proposed by the UN in the Agenda 2030 plan for sustainable development [191]. In this sense, the framework we proposed in this paper can be also seen as a decision of support for policy makers in defining actions and policies to support development of rural areas.

\section{Limitations}

Of course, our paper suffers from some limitations. Methodological choices made in this work, including the selection criteria of the papers to be analyzed, could lead to the exclusion of some interesting works. Selection bias could represent a significant issue in carrying out a systematic literature review. Selective inclusion of studies published only in English (language bias), selective inclusion of studies only from one's own discipline (familiarity bias), and selective inclusion of sources (source bias) could hamper the significance of the study, leading to research datasets that are not completely representative of the entire population of studies [192]. In any case, since our paper aims to give a qualitative picture of the current state of scientific research rather than a quantitative bibliometric analysis, we decided to restrict our search to relevant journal articles in organizational field of study. In any case, although the approach we have adopted is widely consolidated in the scientific literature, further studies can be conducted by expanding the sample of analysis to other sources, such as conference papers, monographs, books, and technical papers. This would allow us to have a comprehensive and exhaustive view of the whole body of knowledge in this domain.

Moreover, the basic assumption underpinned in this work is that scientific research investigated relevant aspects dealing with collaboration in sustainable food supply chain. However, it is possible that some aspects have been neglected or at least under investigated in the literature with respect to what is the actual business practice. Further investigations based on real case studies and interviews are needed to validate our framework. In our review we found many case studies in different agri-food supply chains with heterogeneous characteristics. We have tried to make the framework independent of the type of food produced and distributed by the supply chain so that we can generalize the results of our work. However, future studies could be aimed at defining suitable verticalizations of the framework for specific food chains.

Author Contributions: Conceptualization of the research, S.A. and A.M.F.; supervision, S.A., A.V. and M.F.; methodology, A.M.F. and C.R.; data curation C.R. and A.M.F.; formal analysis, A.M.F., C.R.; validation S.A., M.F. and A.V.; writing-original draft preparation: introduction S.A. and A.M.F.; 2. Collaborative Networks in the agri-food sector C.R. and A.M.F.; methodology S.A. and C.R.; results: 
S.A., A.M.F. and C.R.; discussion, S.A., A.M.F. and A.V., conclusions S.A., M.F. and A.V.; project administration, A.V.; funding acquisition, A.V. and M.F. All authors have read and agreed to the published version of the manuscript.

Funding: This research was partially funded by MISE (Ministero Italiano dello Sviluppo Economico) under the project "MEC—Marketplace Ecosostenibile Calabria": CUP B31B20000520005.

Institutional Review Board Statement: Not applicable.

Informed Consent Statement: Not applicable.

Data Availability Statement: Not applicable.

Conflicts of Interest: The authors declare no conflict of interest.

\section{References}

1. Ammirato, S.; Felicetti, A.M. The Potential of Agritourism in Revitalizing Rural Communities: Some Empirical Results. In Collaborative Systems for Reindustrialization, Proceedings of the 14th IFIP WG 5.5 Working Conference on Virtual Enterprises, Dresden, Germany, 30 September 2013; Camarinha-Matos, L.M., Scherer, R.J., Eds.; Springer: Berlin/Heidelberg, Germany, 2013; Volume 408, pp. $489-497$.

2. Fagioli, F.F.; Diotallevi, F.; Ciani, A. Strengthening the sustainability of rural areas: The role of rural tourism and agritourism. Riv. Econ. Agrar. 2014, 69, 155-169.

3. Ammirato, S.; Felicetti, A.M.; Della Gala, M.; Frega, N.; Volpentesta, A.P. Sustainable Development for Rural Areas: A Survey on the Agritourism Rural Networks. In Collaboration in a Data-Rich World: 18th IFIP WG 5.5 Working Conference on Virtual Enterprises, PRO-VE 2017, Vicenza, Italy, 18-20 September 2017; Camarinha-Matos, L.M., Afsarmanesh, H., Fornasiero, R., Eds.; Springer: Berlin/Heidelberg, Germany, 2017; Volume 506, pp. 564-574.

4. Westhoek, H.J.; Van den Berg, M.; Bakkes, J.A. Scenario development to explore the future of Europe's rural areas. Agric. Ecosyst. Environ. 2006, 114, 7-20. [CrossRef]

5. Diao, X.; Hazell, P.; Thurlow, J. The role of agriculture in African development. World Dev. 2010, 38, 1375-1383. [CrossRef]

6. Sgroi, F.; Di Trapani, A.M.; Testa, R.; Tudisca, S. The rural tourism as development opportunity or farms. The case of direct sales in Sicily. Am. J. Agric. Biol. Sci. 2014, 9, 407-419. [CrossRef]

7. Volpentesta, A.P.; Felicetti, A.M. Research investigation on food information user's behaviour. In Collaborative Networks of Cognitive Systems; Camarinha-Matos, L.M., Afsarmanesh, H., Rezgui, Y., Eds.; Springer: Berlin/Heidelberg, Germany, 2018 ; pp. 190-202.

8. Costa, A.I.; Jongen, W.M.F. New insights into consumer-led food product development. Trends Food Sci. Technol. 2006, 17, 457-465. [CrossRef]

9. Ammirato, S.; Felicetti, A.M. Tourism Breeding Environment: Forms and levels of collaboration in the tourism sector. In Proceedings of the 14th IFIP WG 5.5 Working Conference on Virtual Enterprises, Dresden, Germany, 30 September 2013; Camarinha-Matos, L.M., Scherer, R.J., Eds.; Springer: Berlin/Heidelberg, Germany, 2013; Volume 408, pp. 517-524.

10. Felicetti, A.M.; Volpentesta, A.P.; Ammirato, S. Analyzing app-based food information services: The case of Olive Oil sector. Vine J. Inf. Knowl. Manag. Syst. 2019, 50, 427-453. [CrossRef]

11. Marotta, G.; Nazzaro, C. Public goods production and value creation in wineries: A structural equation modelling. Br. Food J. 2020, 122, 1705-1724. [CrossRef]

12. Nazzaro, C.; Stanco, M.; Marotta, G. The Life Cycle of Corporate Social Responsibility in Agri-Food: Value Creation Models. Sustainability 2020, 12, 1287. [CrossRef]

13. Lindgren, E.; Harris, F.; Dangour, A.D.; Gasparatos, A.; Hiramatsu, M.; Javadi, F.; Haines, A. Sustainable food systems-a health perspective. Sustain. Sci. 2018, 13, 1505-1517. [CrossRef]

14. Addinsall, C.; Scherrer, P.; Weiler, B.; Glencross, K. An ecologically and socially inclusive model of agritourism to support smallholder livelihoods in the South Pacific. Asia Pac. J. Tour. Res. 2017, 22, 301-315. [CrossRef]

15. Volpentesta, A.P.; Felicetti, A.M.; Ammirato, S. Intelligent food information provision to consumers in an internet of food era. In Collaboration in a Data-Rich World; Camarinha-Matos, L.M., Afsarmanesh, H., Fornasiero, R., Eds.; Springer: Cham, Switzerland, 2017; Volume 506, pp. 725-736.

16. Tregear, A. Progressing knowledge in alternative and local food networks: Critical reflections and a research agenda. J. Rural Stud. 2011, 27, 419-430. [CrossRef]

17. Ammirato, S.; Felicetti, A.M. The Agritourism as a Means of Sustainable Development for Rural Communities: A Research from the Field. Int. J. Interdiscip. Envrion. Stud. 2014, 8, 17-29. [CrossRef]

18. Sonnino, R.; Moragues Faus, A.; Maggio, A. Sustainable food security: An emerging research and policy agenda. Int. J. Sociol. Agric. Food 2014, 21, 173-188.

19. Forssell, S.; Lankoski, L. The sustainability promise of alternative food networks: An examination through alternative characteristics. Agric. Hum. Values 2015, 32, 63-75. [CrossRef]

20. Ammirato, S.; Felicetti, A.M.; Raso, C.; Pansera, B.A.; Violi, A. Agritourism and Sustainability: What We Can Learn from a Systematic Literature Review. Sustainability 2020, 12, 9575. [CrossRef] 
21. Volpentesta, A.P.; Ammirato, S. Alternative agrifood networks in a regional area: A case study. Int. J. Comput. Integr. Manuf. 2013, 26, 55-66. [CrossRef]

22. Preston, F. A global Redesign? Shaping the Circular Economy; Chatham House: London, UK, 2012.

23. Wu, X.; Nie, L.; Xu, M.; Yan, F. A perishable food supply chain problem considering demand uncertainty and time deadline constraints: Modeling and application to a high-speed railway catering service. Transp. Res. Part E Logist. Transp. Rev. 2018, 111, 186-209. [CrossRef]

24. Esteso, A.; Alemany, M.M.E.; Ortiz, A. Conceptual framework for managing uncertainty in a collaborative agri-food supply chain context. In Working Conference on Virtual Enterprises; Springer: Cham, Switzerland, 2017; pp. 715-724.

25. Gokarn, S.; Kuthambalayan, T.S. Analysis of challenges inhibiting the reduction of waste in food supply chain. J. Clean. Prod. 2017, 168, 595-604. [CrossRef]

26. Tuni, A.; Rentizelas, A.; Chinese, D. An integrative approach to assess environmental and economic sustainability in multi-tier supply chains. Prod. Plan. Control 2020, 31, 861-882. [CrossRef]

27. Manzini, R.; Accorsi, R. The new conceptual framework for food supply chain assessment. J. Food Eng. 2013, 115, 251-263. [CrossRef]

28. Govindan, K. Sustainable consumption and production in the food supply chain: A conceptual framework. Int. J. Prod. Econ. 2018, 195, 419-431. [CrossRef]

29. Krishnan, R.; Agarwal, R.; Bajada, C.; Arshinder, K. Redesigning a food supply chain for environmental sustainability-An analysis of resource use and recovery. J. Clean. Prod. 2020, 242, 118374. [CrossRef]

30. Denyer, D.; Tranfield, D. Producing a Systematic Review. In The Sage Handbook of Organizational Research Methods; Sage Publications Ltd.: London, UK, 2009; pp. 671-689.

31. Pender, J.L.; Weber, J.G.; Brown, J.P. Sustainable rural development and wealth creation: Five observations based on emerging energy opportunities. Econ. Dev. Q. 2014, 28, 73-86. [CrossRef]

32. Fraser, E.D.; Dougill, A.J.; Mabee, W.E.; Reed, M.; McAlpine, P. Bottom up and top down: Analysis of participatory processes for sustainability indicator identification as a pathway to community empowerment and sustainable environmental management. J. Environ. Manag. 2006, 78, 114-127. [CrossRef]

33. Camarinha-Matos, L.M.; Afsarmanesh, H.; Boucher, X. The role of collaborative networks in sustainability. In Collaborative Networks for a Sustainable World; Camarinha-Matos, L.M., Boucher, X., Eds.; Springer: Berlin/Heidelberg, Germany, 2010; pp. $1-16$.

34. Vermunt, D.A.; Negro, S.O.; Van Laerhoven, F.S.J.; Verweij, P.A.; Hekkert, M.P. Sustainability transitions in the agri-food sector: How ecology affects transition dynamics. Environ. Innov. Soc. Transit. 2020, 36, 236-249. [CrossRef]

35. Camarinha-Matos, L.M.; Afsarmanesh, H. Collaborative networks: A new scientific discipline. J. Intell. Manuf. 2005, 16, 439-452. [CrossRef]

36. Scott, A.; Storper, M. Regions, globalization, development. Reg. Stud. 2003, 37, 579-593. [CrossRef]

37. Golušin, M.; Ivanović, O.M.; Andrejević, A.; Vučenov, S. Survey of Social and Economic Growth in Se Europe-A New Conceptual Frame for Sustainability Metrics. J. Econ. Surv. 2014, 28, 152-168. [CrossRef]

38. Lowndes, V.; Skelcher, C. The dynamics of multiorganizational partnerships: An analysis of changing modes of governance. Public Adm. 1998, 76, 313-333. [CrossRef]

39. Serra, T.; Poli, E. Shadow prices of social capital in rural India, a nonparametric approach. Eur. J. Oper. Res. 2015, 240, 892-903. [CrossRef]

40. Camarinha-Matos, L.M.; Afsarmanesh, H. A framework for virtual organization creation in a breeding environment. Annu. Rev. Control 2007, 31, 119-135. [CrossRef]

41. Li, D.; Wang, X.; Chan, H.K.; Manzini, R. Sustainable food supply chain management. Int. J. Prod. Econ. 2014, 152, 1-8. [CrossRef]

42. Golini, R.; Moretto, A.; Caniato, F.; Caridi, M.; Kalchschmidt, M. Developing sustainability in the Italian meat supply chain: An empirical investigation. Int. J. Prod. Res. 2017, 55, 1183-1209. [CrossRef]

43. León-Bravo, V.; Caniato, F.; Caridi, M.; Johnsen, T. Collaboration for sustainability in the food supply chain: A multi-stage study in Italy. Sustainability 2017, 9, 1253. [CrossRef]

44. Benedek, Z.; Fertő, I.; Szente, V. The Multiplier Effects of Food Relocalization: A Systematic Review. Sustainability 2020, $12,3524$. [CrossRef]

45. McGehee, N.G.; Kim, K. Motivation for agri-tourism entrepreneurship. J. Travel Res. 2004, 43, 161-170. [CrossRef]

46. Van der Ploeg, J.D. Theorizing agri-food economies. Agriculture 2016, 6, 30. [CrossRef]

47. Camarinha-Matos, L.M.; Fornasiero, R.; Ramezani, J.; Ferrada, F. Collaborative Networks: A Pillar of Digital Transformation. Appl. Sci. 2019, 9, 5431. [CrossRef]

48. Allen, P.; Simmons, M.F.; Goodman, M.; Warner, K. Shifting plates in the agrifood landscape: The tectonics of alternative agrifood initiatives in California. J. Rural Stud. 2003, 19, 61-75. [CrossRef]

49. Wright, W.; Score, M.; Conner, D. Food system makers: Motivational frames for catalyzing agri-food development through multi-stakeholder collaboration. Community Dev. 2007, 38, 39-59. [CrossRef]

50. Maier, P.; Klein, O.; Schumacher, K.P. Ecological benefits through alternative food networks? Prospects of regional barley-malt-beer value chains in Bavaria, Germany. J. Clean. Prod. 2020, 265, 121848. [CrossRef] 
51. Toop, T.A.; Ward, S.; Oldfield, T.; Hull, M.; Kirby, M.E.; Theodorou, M.K. AgroCycle-Developing a circular economy in agriculture. Energy Procedia 2017, 123, 76-80. [CrossRef]

52. Murray, A.; Skene, K.; Haynes, K. The circular economy: An interdisciplinary exploration of the concept and application in a global context. J. Bus. Ethics 2017, 140, 369-380. [CrossRef]

53. Derqui, B.; Fayos, T.; Fernandez, V. Towards a more sustainable food supply chain: Opening up invisible waste in food service. Sustainability 2016, 8, 693. [CrossRef]

54. Manteghi, Y.; Arkat, J.; Mahmoodi, A.; Farvaresh, H. Competition and cooperation in the sustainable food supply chain with a focus on social issues. J. Clean. Prod. 2021, 285, 124872. [CrossRef]

55. Sala, S.; Ciuffo, B.; Nijkamp, P. A systemic framework for sustainability assessment. Ecol. Econ. 2015, 119, 314-325. [CrossRef]

56. Principato, L.; Ruini, L.; Guidi, M.; Secondi, L. Adopting the circular economy approach on food loss and waste: The case of Italian pasta production. Resour. Conserv. Recycl. 2019, 144, 82-89. [CrossRef]

57. Halloran, A.; Clement, J.; Kornum, N.; Bucatariu, C.; Magid, J. Addressing food waste reduction in Denmark. Food Policy 2014, 49, 294-301. [CrossRef]

58. Engström, R.; Carlsson-Kanyama, A. Food losses in food service institutions Examples from Sweden. Food Policy 2004, 29, 203-213. [CrossRef]

59. Pirani, S.I.; Arafat, H.A. Reduction of food waste generation in the hospitality industry. J. Clean. Prod. 2016, 132, 129-145. [CrossRef]

60. Zimon, D.; Madzik, P.; Domingues, P. Development of key processes along the supply chain by implementing the ISO 22000 standard. Sustainability 2020, 12, 6176. [CrossRef]

61. Cuéllar-Padilla, M.; Ganuza-Fernandez, E. We don't want to be officially certified! Reasons and implications of the participatory guarantee systems. Sustainability 2018, 10, 1142. [CrossRef]

62. Borrello, M.; Caracciolo, F.; Lombardi, A.; Pascucci, S.; Cembalo, L. Consumers' perspective on circular economy strategy for reducing food waste. Sustainability 2017, 9, 141. [CrossRef]

63. Principato, L. Food Waste at the Consumer Level. In A Comprehensive Literature Review; Springer International Publishing: Cham, Switzerland, 2018.

64. Principato, L.; Secondi, L.; Pratesi, C.A. Reducing food waste: An investigation on the behaviour of Italian Youths. Br. Food J. 2015, 117, 731-748. [CrossRef]

65. Principato, L.; Pratesi, C.A.; Secondi, L. Towards zero waste: An exploratory study on restaurant managers. Int. J. Hosp. Manag. 2018, 74, 130-137. [CrossRef]

66. Secondi, L.; Principato, L.; Laureti, T. Household food waste behaviour in EU-27 countries: A multilevel analysis. Food Policy 2015, 56, 25-40. [CrossRef]

67. Principato, L.; Secondi, L.; Cicatiello, C.; Mattia, G. Caring more about food: The unexpected positive effect of the Covid-19 lockdown on household food management and waste. Socio-Econ. Plan. Sci. 2020, 100953, in press. [CrossRef]

68. Ammirato, S.; Linzalone, R.; Felicetti, A.M. Knowledge management in pandemics. A critical literature review. Knowl. Manag. Res. Pract. 2020, 1-12. [CrossRef]

69. Batista, L.; Dora, M.; Toth, J.; Molnár, A.; Malekpoor, H.; Kumari, S. Knowledge management for food supply chain synergies-a maturity level analysis of SME companies. Prod. Plan. Control 2019, 30, 995-1004. [CrossRef]

70. Archambault, É.; Campbell, D.; Gingras, Y.; Larivière, V. Comparing bibliometric statistics obtained from the Web of Science and Scopus. J. Am. Soc. Inf. Sci. Technol. 2009, 60, 1320-1326. [CrossRef]

71. Piccarozzi, M.; Aquilani, B.; Gatti, C. Industry 4.0 in management studies: A systematic literature review. Sustainability 2018, 10, 3821. [CrossRef]

72. Vicente-Sáez, R. Martínez-Fuentes, C. Open Science now: A systematic literature review for an integrated definition. J. Bus. Res. 2018, 88, 428-436. [CrossRef]

73. Camarinha-Matos, L.M.; Afsarmanesh, H. On reference models for collaborative networked organizations. Int. J. Prod. Res. 2008, 46, 2453-2469. [CrossRef]

74. Glavič, P.; Lukman, R. Review of sustainability terms and their definitions. J. Clean. Prod. 2007, 15, 1875-1885. [CrossRef]

75. Moore, J.E.; Mascarenhas, A.; Bain, J.; Straus, S.E. Developing a comprehensive definition of sustainability. Implement. Sci. 2017, 12, 110. [CrossRef]

76. Bergman, M.M.; Bergman, Z.; Berger, L. An empirical exploration, typology, and definition of corporate sustainability. Sustainability 2017, 9, 753. [CrossRef]

77. Ammirato, S.; Della Gala, M.; Volpentesta, A.P. Alternative agrifood networks as learning communities: Some issues for a classification model. In World Summit on Knowledge Society; Springer: Berlin/Heidelberg, Germany, 2011; pp. $293-300$.

78. Galvagno, M.; Dalli, D. Theory of value co-creation: A systematic literature review. Manag. Serv. Qual. Int. J. 2014, 24, 643-683. [CrossRef]

79. Merli, R.; Preziosi, M.; Acampora, A. How do scholars approach the circular economy? A systematic literature review. J. Clean. Prod. 2017, 178, 703-722. [CrossRef]

80. Sivarajah, U.; Kamal, M.M.; Irani, Z.; Weerakkody, V. Critical analysis of Big Data challenges and analytical methods. J. Bus. Res. 2018, 70, 263-286. [CrossRef]

81. Blei, D.M. Probabilistic topic models. Commun. ACM 2012, 55, 77-84. [CrossRef] 
82. Chang, J.; Gerrish, S.; Wang, C.; Boyd-Graber, J.; Blei, D. Reading tea leaves: How humans interpret topic models. Adv. Neural Inf. Process. Syst. 2009, 22, 288-296.

83. Ammirato, S.; Felicetti, A.M.; Linzalone, R.; Volpentesta, A.P.; Schiuma, G. A systematic literature review of revenue management in passenger transportation. Meas. Bus. Excel. 2020, 24, 223-242. [CrossRef]

84. Muawanah, U.; Pomeroy, R.S.; Marlessy, C. Revisiting fish wars: Conflict and collaboration over fisheries in Indonesia. Coast. Manag. 2012, 40, 279-288. [CrossRef]

85. Lozano, R. Collaboration as a pathway for sustainability. Sustain. Dev. 2007, 15, 370-381. [CrossRef]

86. Schuster, M.; Maertens, M. Do private standards create exclusive supply chains? New evidence from the Peruvian asparagus export sector. Food Policy 2013, 43, 291-305. [CrossRef]

87. Hammoudi, A.; Hoffmann, R.; Surry, Y. Food safety standards and agri-food supply chains: An introductory overview. Eur. Rev. Agric. Econ. 2009, 36, 469-478. [CrossRef]

88. Qu, W.G.; Yang, Z. The effect of uncertainty avoidance and social trust on supply chain collaboration. J. Bus. Res. 2015, 68, 911-918. [CrossRef]

89. Bastian, J.; Zentes, J. Supply chain transparency as a key prerequisite for sustainable agri-food supply chain management. Int. Rev. Retail Distrib. Consum. Res. 2013, 23, 553-570. [CrossRef]

90. Wognum, P.N.; Bremmers, H.; Trienekens, J.H.; van der Vorst, J.G.; Bloemhof, J.M. Systems for sustainability and transparency of food supply chains-Current status and challenges. Adv. Eng. Inform. 2011, 25, 65-76. [CrossRef]

91. Trienekens, J.H.; Wognum, P.M.; Beulens, A.J.; van der Vorst, J.G. Transparency in complex dynamic food supply chains. Adv. Eng. Inform. 2012, 26, 55-65. [CrossRef]

92. Shafiee-Jood, M.; Cai, X. Reducing food loss and waste to enhance food security and environmental sustainability. Environ. Sci. Technol. 2016, 50, 8432-8443. [CrossRef] [PubMed]

93. Kirwan, J.; Maye, D.; Brunori, G. Acknowledging complexity in food supply chains when assessing their performance and sustainability. J. Rural Stud. 2017, 52, 21-32. [CrossRef]

94. Susanty, A.; Bakhtiar, A.; Jie, F.; Muthi, M. The empirical model of trust, loyalty, and business performance of the dairy milk supply chain. Br. Food J. 2017, 119, 2765-2787. [CrossRef]

95. León-Bravo, V.; Caniato, F.; Caridi, M. Sustainability assessment in the food supply chain: Study of a certified product in Italy. Prod. Plan. Control 2020, 1-18, in press.

96. Maestrini, V.; Luzzini, D.; Caniato, F.; Maccarrone, P.; Ronchi, S. Measuring supply chain performance: A lifecycle framework and a case study. Int. J. Oper. Prod. Manag. 2018, 38, 934-956. [CrossRef]

97. Genovese, A.; Morris, J.; Piccolo, C.; Koh, S.L. Assessing redundancies in environmental performance measures for supply chains. J. Clean. Prod. 2017, 167, 1290-1302. [CrossRef]

98. Bloemhof, J.M.; van der Vorst, J.G.; Bastl, M.; Allaoui, H. Sustainability assessment of food chain logistics. Int. J. Logist. Res. Appl. 2015, 18, 101-117. [CrossRef]

99. Moazzam, M.; Akhtar, P.; Garnevska, E.; Marr, N.E. Measuring agri-food supply chain performance and risk through a new analytical framework: A case study of New Zealand dairy. Prod. Plan. Control 2018, 29, 1258-1274. [CrossRef]

100. Kähkönen, A.-K.; Lintukangas, K.; Hallikas, J. Sustainable supply management practices: Making a difference in a firm's sustainability performance. Supply Chain Manag. 2018, 23, 518-530. [CrossRef]

101. Gualandris, J.; Klassen, R.D.; Vachon, S.; Kalchschmidt, M. Sustainable evaluation and verification in supply chains: Aligning and leveraging accountability to stakeholders. J. Oper. Manag. 2015, 38, 1-13. [CrossRef]

102. Banterle, A.; Cereda, E.; Fritz, M. Labelling and Sustainability in Food Supply Networks: A Comparison between the German and Italian Markets. Br. Food J. 2013, 115, 769-783. [CrossRef]

103. Beske, P.; Land, A.; Seuring, S. Sustainable Supply Chain Management Practices and Dynamic Capabilities in the Food Industry: A Critical Analysis of the Literature. Int. J. Prod. Econ. 2014, 152, 131-143. [CrossRef]

104. Seuring, S.; Müller, M. From a literature review to a conceptual framework for sustainable supply chain management. J. Clean. Prod. 2008, 16, 1699-1710. [CrossRef]

105. Pullman, M.E.; Maloni, M.J.; Carter, C.R. Food for thought: Social versus environmental sustainability practices and performance outcomes. J. Supply Chain Manag. 2009, 45, 38-54. [CrossRef]

106. Gava, O.; Galli, F.; Bartolini, F.; Brunori, G. Linking sustainability with geographical proximity in food supply chains. An indicator selection framework. Agriculture 2018, 8, 130. [CrossRef]

107. Santos, R.R.; Guarnieri, P. Social gains for artisanal agroindustrial producers induced by cooperation and collaboration in agri-food supply chain. Soc. Responsib. J. 2020, 16, 1-19. [CrossRef]

108. Malak-Rawlikowska, A.; Majewski, E.; Wass, A.; Borgen, S.O.; Csillag, P.; Donati, M.; Nguyen, A. Measuring the economic, environmental, and social sustainability of short food supply chains. Sustainability 2019, 11, 4004. [CrossRef]

109. Marqui, A.C.; Moura, K.S.D.; Alcântara, R.L.C. Collaborative supply chain: A conceptual model for operationalisation. Int. J. Manag. Decis. Mak. 2013, 12, 195-214. [CrossRef]

110. Grosvold, J.; Hoejmose, S.U.; Roehrich, J.K. Squaring the circle: Management, measurement and performance of sustainability in supply chains. Supply Chain Manag. Int. J. 2014, 19, 292-305. [CrossRef]

111. Moharana, H.S.; Murty, J.S.; Senapati, S.K.; Khuntia, K. Coordination, collaboration and integration for supply chain management. Int. J. Intersci. Manag. Rev. 2012, 2, 46-50. 
112. Spekman, R.E.; Kamauff, J.W.; Myhr, N. An empirical investigation into supply chain management: A perspective on partnerships. Supply Chain Manag. Int. J. 1998, 3, 53-67. [CrossRef]

113. Volpentesta, A.P.; Ammirato, S.; Della Gala, M. Classifying short agrifood supply chains under a knowledge and social learning perspective. Rural Soc. 2013, 22, 217-229. [CrossRef]

114. Rota, C.; Pugliese, P.; Hashem, S.; Zanasi, C. Assessing the level of collaboration in the Egyptian organic and fair trade cotton chain. J. Clean. Prod. 2018, 170, 1665-1676. [CrossRef]

115. Wiengarten, F.; Pagell, M.; Fynes, B. Supply chain environmental investments in dynamic industries: Comparing investment and performance differences with static industries. Int. J. Prod. Econ. 2012, 135, 541-551. [CrossRef]

116. Aschemann-Witzel, J.; De Hooge, I.E.; Rohm, H.; Normann, A.; Bossle, M.B.; Grønhøj, A.; Oostindjer, M. Key characteristics and success factors of supply chain initiatives tackling consumer-related food waste-A multiple case study. J. Clean. Prod. 2017, 155, 33-45. [CrossRef]

117. Ling, E.K.; Wahab, S.N. Integrity of food supply chain: Going beyond food safety and food quality. Int. J. Product. Qual. Manag. 2020, 29, 216-232. [CrossRef]

118. Rebs, T.; Brandenburg, M.; Seuring, S. System dynamics modeling for sustainable supply chain management: A literature review and systems thinking approach. J. Clean. Prod. 2019, 208, 1265-1280. [CrossRef]

119. Kirci, M.; Seifert, R. Dynamic capabilities in sustainable supply chain management: A theoretical framework. Supply Chain Forum Int. J. 2015, 16, 2-15. [CrossRef]

120. Pohlmann, C.R.; Scavarda, A.J.; Alves, M.B.; Korzenowski, A.L. The role of the focal company in sustainable development goals: A Brazilian food poultry supply chain case study. J. Clean. Prod. 2020, 245, 118798. [CrossRef]

121. Sellitto, M.A.; Hermann, F.F. Prioritization of green practices in GSCM: Case study with companies of the peach industry. Gest. Prod. 2016, 23, 871-886. [CrossRef]

122. Schmidt, F.; Zanini, R.; Korzenowski, A.; Junior, R.S.; do Nascimento, K.X. Evaluation of sustainability practices in small and medium-sized manufacturing enterprises in southern Brazil. Sustainability 2018, 10, 2460. [CrossRef]

123. Marsden, T.; Banks, J.; Bristow, G. Food supply chain approaches: Exploring their role in rural development. Sociol. Rural. 2000, 40, 424-438. [CrossRef]

124. Renting, H.; Marsden, T.K.; Banks, J. Understanding alternative food networks: Exploring the role of short food supply chains in rural development. Environ. Plan. 2003, 35, 393-411. [CrossRef]

125. Sacchi, G.; Belletti, G.; Biancalani, M.; Lombardi, G.; Stefani, G. The valorisation of wheat production through locally-based bread chains: Experiences from Tuscany. J. Rural Stud. 2019, 71, 23-35. [CrossRef]

126. Volpentesta, A.P.; Ammirato, S.; Della Gala, M. Knowledge exchange and social learning opportunities in direct agri-food chains. In 14th IFIP WG 5.5 Working Conference on Virtual Enterprises, PRO-VE 2012, Dresden, Germany 2012; Springer: Berlin/Heidelberg, Germany, 2012; pp. 340-348.

127. Atzberger, C. Advances in remote sensing of agriculture: Context description, existing operational monitoring systems and major information needs. Remote Sens. 2013, 5, 949-981. [CrossRef]

128. Coley, D.; Howard, M.; Winter, M. Food miles: Time for a re-think? Br. Food J. 2011, 113, 919-934. [CrossRef]

129. Van Evert, F.K.; Gaitán-Cremaschi, D.; Fountas, S.; Kempenaar, C. Can precision agriculture increase the profitability and sustainability of the production of potatoes and olives? Sustainability 2017, 9, 1863. [CrossRef]

130. Accorsi, R.; Cholette, S.; Manzini, R.; Tufano, A. A hierarchical data architecture for sustainable food supply chain management and planning. J. Clean. Prod. 2018, 203, 1039-1054. [CrossRef]

131. Zhu, Z.; Chu, F.; Dolgui, A.; Chu, C.; Zhou, W.; Piramuthu, S. Recent advances and opportunities in sustainable food supply chain: A model-oriented review. Int. J. Prod. Res. 2018, 56, 5700-5722. [CrossRef]

132. Daneshvar Kakhki, M.; Gargeya, V.B. Information systems for supply chain management: A systematic literature analysis. Int. J. Prod. Res. 2019, 57, 5318-5339. [CrossRef]

133. Jagtap, S.; Rahimifard, S. The digitisation of food manufacturing to reduce waste-Case study of a ready meal factory. Waste Manag. 2019, 87, 387-397. [CrossRef]

134. Thöni, A.; Tjoa, A.M. Information technology for sustainable supply chain management: A literature survey. Enterp. Inf. Syst. 2017, 11, 828-858. [CrossRef]

135. Manning, L.; Birchmore, I.; Morris, W. Swans and Elephants: A typology to capture the challenges of food supply chain risk assessment. Trends Food Sci. Technol. 2020, 106, 288-297. [CrossRef] [PubMed]

136. Kataike, J.; Aramyan, L.H.; Schmidt, O.; Molnár, A.; Gellynck, X. Measuring chain performance beyond supplier-buyer relationships in agri-food chains. Supply Chain Manag. 2019, 24, 484-497. [CrossRef]

137. Barnett, I.; Hernandez, K.; Ramalingam, B.; Levy, A.; Oppenheimer, C.; Valters, C. Can ICTenabled real-time data contribute to adaptive management in development programming? Dev. Pract. 2009, 29, 287-299. [CrossRef]

138. Kumar, A.; Singh, R.K.; Modgil, S. Exploring the relationship between ICT, SCM practices and organizational performance in agri-food supply chain. Benchmarking Int. J. 2020, 27, 1003-1041. [CrossRef]

139. Galvez, J.F.; Mejuto, J.C.; Simal-Gandara, J. Future challenges on the use of blockchain for food traceability analysis. Trends Anal. Chem. 2018, 107, 222-232. [CrossRef]

140. Haleem, A.; Khan, S.; Khan, M.I. Traceability implementation in food supply chain: A grey-DEMATEL approach. Inf. Process. Agric. 2019, 6, 335-348. [CrossRef] 
141. Volpentesta, A.P.; Della Gala, M. Analyzing mobile services in alternative agrifood networks. In Proceedings of the 14th IFIP WG 5.5 Working Conference on Virtual Enterprises, Dresden, Germany, 30 September 2013; Camarinha-Matos, L.M., Scherer, R.J., Eds.; Springer: Berlin/Heidelberg, Germany, 2013; Volume 408, pp. 314-323.

142. Ammirato, S.; Felicetti, A.M.; Della Gala, M. Rethinking tourism destinations: Collaborative network models for the tourist 2.0. Int. J. Knowl. Based Dev. 2015, 6, 178-201. [CrossRef]

143. Volpentesta, A.P.; Felicetti, A.M. Identifying opinion leaders in time-dependent commercial social networks. In Collaborative Networks in the Internet of Services; Camarinha-Matos, L.M., Xu, L., Asfarmanesh, H., Eds.; Springer: Berlin/Heidelberg, Germany, 2012; pp. 571-581.

144. Volpentesta, A.P.; Felicetti, A.M.; Frega, N. Organizational and technological aspects of a platform for collective food awareness. Adv. Hum. Comput. Interact. 2018, 8608407. [CrossRef]

145. Volpentesta, A.P.; Felicetti, A.M.; Frega, N. Collaboration Networks for Information Empowerment of Food Consumers. In Collaborative Networks and Digital Transformation, Proceedings of the 20th IFIP WG 5.5 Working Conference on Virtual Enterprises, PRO-VE 2019, Torino, Italy, 23-25 September 2019; Camarinha-Matos, L.M., Afsarmanesh, H., Antonelli, D., Eds.; Springer: Cham, Switzerland, 2019; Volume 568, pp. 457-466.

146. Singh, R.; Centobelli, P.; Cerchione, R. Evaluating partnerships in sustainability-oriented food supply chain: A five-stage performance measurement model. Energies 2018, 11, 3473.

147. Chan, H.Y.; Abdul Halim-Lim, S.; Tan, T.B.; Kamarulzaman, N.H.; Jamaludin, A.A.; Wan-Mohtar, W.A.A.Q.I. Exploring the Drivers and the Interventions towards Sustainable Food Security in the Food Supply Chain. Sustainability 2020, 12, 7890. [CrossRef]

148. Wang, P.; Watts, A. Formation of buyer-seller trade networks in a quality-differentiated product market. Can. J. Econ. 2006, 39, 971-1004. [CrossRef]

149. Sarpong, S. Traceability and supply chain complexity: Confronting the issues and concerns. Eur. Bus. Rev. 2014, 26, 271-284. [CrossRef]

150. Dora, M. Collaboration in a circular economy: Learning from the farmers to reduce food waste. J. Enterp. Inf. Manag. 2019, 33, 769-789. [CrossRef]

151. O'Reilly, S.; Haines, M.; Arfini, F. Food SME networks: Process and governance-The case of Parma ham. J. Chain Netw. Sci. 2003, 3, 21-32. [CrossRef]

152. Dentoni, D.; Menozzi, D.; Capelli, M.G. Group heterogeneity and cooperation on the geographical indication regulation: The case of the "Prosciutto di Parma" Consortium. Food Policy 2012, 37, 207-216. [CrossRef]

153. Van Der Vorst, J.G.; Tromp, S.O.; Zee, D.J.V.D. Simulation modelling for food supply chain redesign; integrated decision making on product quality, sustainability and logistics. Int. J. Prod. Res. 2009, 47, 6611-6631. [CrossRef]

154. Soto-Silva, W.E.; Nadal-Roig, E.; González-Araya, M.C.; Pla-Aragones, L.M. Operational research models applied to the fresh fruit supply chain. Eur. J. Oper. Res. 2016, 251, 345-355. [CrossRef]

155. Dos Santos, L.M.R.; Costa, A.M.; Arenales, M.N.; Santos, R.H.S. Sustainable Vegetable Crop Supply Problem. Eur. J. Oper. Res. 2010, 204, 639-647. [CrossRef]

156. Costa, A.M.; dos Santos, L.M.R.; Alem, D.J.; Santos, R.H. Sustainable Vegetable Crop Supply Problem with Perishable Stocks. Ann. Oper. Res. 2014, 219, 1-19. [CrossRef]

157. Broek, J.V.D.; Schutz, P.; Stougie, L.; Tomasgard, A. Location of Slaughterhouses under Economies of Scale. Eur. J. Oper. Res. 2006, 175, 740-750. [CrossRef]

158. Schütz, P.; Stougie, L.; Tomasgard, A. Stochastic Facility Location with General Long-run Costs and Convex Short-run Costs. Comput. Oper. Res. 2008, 35, 2988-3000. [CrossRef]

159. Orgut, I.S.; Ivy, J.; Uzsoy, R.; Wilson, J.R. Modeling for the Equitable and Effective Distribution of Donated Food under Capacity Constraints. IIE Trans. 2016, 48, 252-266. [CrossRef]

160. Alfandari, L.; Plateau, A.; Schepler, X. A Branch-and-price-and-cutApproach for Sustainable Crop Rotation Planning. Eur. J. Oper. Res. 2015, 241, 872-879. [CrossRef]

161. Accorsi, R.; Cholette, S.; Manzini, R.; Pini, C.; Penazzi, S. The Land-network Problem: Ecosystem Carbon Balance in Planning Sustainable Agro-food Supply Chains. J. Clean. Prod. 2016, 112, 158-171. [CrossRef]

162. Govindan, K.; Jafarian, A.; Khodaverdi, R.; Devika, K. Two-echelon Multiple-vehicle Location-routing Problem with Time Windows for Optimization of Sustainable Supply Chain Network of Perishable Food. Int. J. Prod. Econ. 2014, 152, 9-28. [CrossRef]

163. Bortolini, M.; Faccio, M.; Ferrari, E.; Gamberi, M.; Pilati, F. Fresh Food Sustainable Distribution: Cost, Delivery Time and Carbon Footprint Three-objective Optimization. J. Food Eng. 2016, 174, 56-67. [CrossRef]

164. Azadnia, A.H.; Saman, M.Z.M.; Wong, K.Y. Sustainable Supplier Selection and Order Lot-sizing:An Integrated Multi-objective Decision-making Process. Int. J. Prod. Res. 2015, 53, 383-408. [CrossRef]

165. Violi, A.; Laganà, D.; Paradiso, R. The inventory routing problem under uncertainty wuth perishable products: An application in the agri-food supply chain. Soft Comput. 2020, 24, 13725-13740. [CrossRef]

166. Guarino, F.; Falcone, G.; Stillitano, T.; De Luca, A.I.; Gulisano, G.; Mistretta, M.; Strano, A. Life cycle assessment of olive oil: A case study in southern Italy. J. Environ. Manag. 2019, 238, 396-407. [CrossRef]

167. Notarnicola, B.; Sala, S.; Anton, A.; McLaren, S.J.; Saouter, E.; Sonesson, U. The role of life cycle assessment in supporting sustainable agri-food systems: A review of the challenges. J. Clean. Prod. 2017, 140, 399-409. [CrossRef] 
168. De Luca, A.I.; Falcone, G.; Stillitano, T.; Iofrida, N.; Strano, A.; Gulisano, G. Evaluation of sustainable innovations in olive growing systems: A Life Cycle Sustainability Assessment case study in southern Italy. J. Clean. Prod. 2018, 171, 1187-1202. [CrossRef]

169. Manfredi, M.; Vignali, G. Life Cycle Assessment of a Packaged Tomato Puree: A Comparison of Environmental Impacts Produced by Different Life Cycle Phases. J. Clean. Prod. 2014, 73, 275-284. [CrossRef]

170. Loiseau, E.; Colin, M.; Alaphilippe, A.; Coste, G.; Roux, P. To what extent are short food supply chains (SFSCs) environmentally friendly? Application to French apple distribution using Life Cycle Assessment. J. Clean. Prod. 2020, 276, 124166. [CrossRef]

171. Ivanov, D.; Sokolov, B.; Solovyeva, I.; Dolgui, A.; Jie, F. Dynamic recovery policies for time-critical supply chains under conditions of ripple effect. Int. J. Prod. Res. 2016, 54, 7245-7258. [CrossRef]

172. Kumar, S.; Nigmatullin, A. A system dynamics analysis of food supply chains-Case study with non-perishable products. Simul. Model. Pract. Theory 2011, 19, 2151-2168. [CrossRef]

173. Taghikhah, F.; Voinov, A.; Shukla, N.; Filatova, T.; Anufriev, M. Integrated modeling of extended agro-food supply chains: A systems approach. Eur. J. Oper. Res. 2020, 288, 852-868. [CrossRef]

174. Zhu, Q.; Krikke, H. Managing a sustainable and resilient perishable food supply chain (PFSC) after an outbreak. Sustainability 2020, 12, 5004. [CrossRef]

175. Ammirato, S.; Sofo, F.; Felicetti, A.M.; Raso, C. The potential of IoT in redesigning the bank branch protection system: An Italian case study. Bus. Process Manag. J. 2019, 25, 1441-1473. [CrossRef]

176. Todorovic, V.; Maslaric, M.; Bojic, S.; Jokic, M.; Mircetic, D.; Nikolicic, S. Solutions for more sustainable distribution in the short food supply chains. Sustainability 2018, 10, 3481. [CrossRef]

177. Pizzuti, T.; Mirabelli, G. The Global Track\&Trace System for food: General framework and functioning principles. J. Food Eng. 2015, 159, 16-35.

178. Verdouw, C.N.; Beulens, A.J.M.; Trienekens, J.H.; Van der Vorst, J.G.A.J. A framework for modelling business processes in demand-driven supply chains. Prod. Plan. Control 2011, 22, 365-388. [CrossRef]

179. Sundarakani, B.; Abdul Razzak, H.; Manikandan, S. Creating a competitive advantage in the global flight catering supply chain: A case study using SCOR model. Int. J. Logist. Res. Appl. 2018, 21, 481-501. [CrossRef]

180. Krishnan, R.; Yen, P.; Agarwal, R.; Arshinder, K.; Bajada, C. Collaborative innovation and sustainability in the food supply chain-evidence from farmer producer organisations. Resour. Conserv. Recycl. 2020, 105253, in press. [CrossRef]

181. Macedo, P.; Abreu, A.; Camarinha-Matos, L.M. Modelling a collaborative network in the agri-food sector using ARCON framework: The PROVE case study. In Working Conference on Virtual Enterprises; Springer: Berlin/Heidelberg, Germany, 2012; pp. 329-339.

182. Molina-Morales, F.X.; Belso-Martínez, J.A.; Más-Verdú, F.; Martínez-Cháfer, L. Formation and dissolution of inter-firm linkages in lengthy and stable networks in clusters. J. Bus. Res. 2015, 68, 1557-1562. [CrossRef]

183. Romero, D.; Galeano, N.; Molina, A. Mechanisms for assessing and enhancing organisations' readiness for collaboration in collaborative networks. Int. J. Prod. Res. 2009, 47, 4691-4710. [CrossRef]

184. Polyantchikov, I.; Shevtshenko, E.; Karaulova, T.; Kangilaski, T.; Camarinha-Matos, L.M. Virtual enterprise formation in the context of a sustainable partner network. Ind. Manag. Data Syst. 2017, 117, 1446-1468. [CrossRef]

185. Dania, W.A.P.; Xing, K.; Amer, Y. Collaboration behavioural factors for sustainable agri-food supply chains: A systematic review. J. Clean. Prod. 2018, 186, 851-864. [CrossRef]

186. Berti, G.; Mulligan, C. Competitiveness of small farms and innovative food supply chains: The role of food hubs in creating sustainable regional and local food systems. Sustainability 2016, 8, 616. [CrossRef]

187. Batista, L.; Bourlakis, M.; Liu, Y.; Smart, P.; Sohal, A. Supply chain operations for a circular economy. Prod. Plan. Control 2018, 29, 419-424. [CrossRef]

188. Kiss, K.; Ruszkai, C.; Takács-György, K. Examination of Short Supply Chains Based on Circular Economy and Sustainability Aspects. Resources 2019, 8, 161. [CrossRef]

189. Vlajic, J.V.; Mijailovic, R.; Bogdanova, M. Creating loops with value recovery: Empirical study of fresh food supply chains. Prod. Plan. Control 2018, 29, 522-538. [CrossRef]

190. Ferrara, M.; Khademi, M.; Salimi, M.; Sharifi, S. A dynamic Stackelberg game of supply chain for a corporate social responsibility. Discret. Dyn. Nat. Soc. 2017, 8656174. [CrossRef]

191. United Nations. The Sustainable Development Goals Report. 2020. Available online: https://unstats.un.org/sdgs/report/2020 /The-Sustainable-Development-Goals-Report-2020.pdf (accessed on 27 October 2020).

192. Rothstein, H.R.; Sutton, A.J.; Borenstein, M. Publication bias in meta-analysis. In Publication Bias in Meta-Analysis: Prevention, Assessment and Adjustments; Rothstein, H.R., Sutton, A.J., Borenstein, M., Eds.; John Wiley \& Sons, Ltd.: Hoboken, NJ, USA, 2005. 